\title{
An integrated approach to identify suitable areas for built-up development using GIS-based multi-criteria analysis and AHP in Siliguri planning area, India
}

\author{
Arjun Saha ${ }^{1}$ (D) $\cdot$ Ranjan Roy ${ }^{1}$
}

Received: 30 October 2020 / Accepted: 9 February 2021 / Published online: 1 March 2021

(c) The Author(s) 2021 OPEN

\begin{abstract}
Unplanned and haphazard built-up growth due to immense pressure of population is a common problem for maximum cities of developing countries which paves to create urban sprawl by capturing spacious areas of natural environment. For this, selection of suitable places for built-up development by maintaining ecological balance has become inevitable part for proper urban planning. Siliguri planning area, which has witnessed a tremendous growth in built-up features after the 1990, has been chosen for this work to find out best places for future built-up development with minimum effects on different natural features and also calculates the amount of different types of suitability which will be transferred from different land use and land cover categories in near future which is a novelty of this work. The work has been executed through GIS-based multi-criteria analysis, and a total of nine criteria have been taken to locate best places for built-up development. Analytic hierarchy process or AHP has been used to calculate weights of each criterion by using pair wise comparison matrix. Final site suitability map has been prepared with four different classes: high suitable, moderate suitable, less suitable and restricted area and the percentage of land is high in moderate suitable category that is $52.33 \%$ which covers the intermediary portion, mainly wastelands and agricultural land of the study area with higher facility of accessibility. Results from this work would be helpful for the planners, stakeholders, policy makers by identifying best locations for the intensive developmental projects in near future.
\end{abstract}

Keywords Urban sprawl · Built up · Site suitability · Multi-criteria · Analytic hierarchy process · Pair wise comparison matrix

\section{Introduction}

Urban growth is a serious and alarming issue which can be defined by change of spatial features as well as demographic structures and also refers to the increase importance of towns and cities for the concentration of population [1, 2]. Simply, it is an expansion of urbanized land category that is built up by urban extension [3]. Most of the cities around the world have been facing this problem of urban growth [4] though it is more severe in developing countries like India $[5,6]$ due to the excessive growth of urban population and economic growth which stimulates people to migrate from neighbouring rural areas to settle there and simultaneously increases households and other impervious surfaces which in a single term built up mostly in an unplanned way and leads to decrease the spacious areas of natural environment like, forests, agricultural land and also rural lands $[7,8]$. These unplanned, unorganized and haphazard patches of built-up growth pave the way to create urban sprawl [9].

Due to this unplanned growth of built up or urban sprawling and unprecedented population growth and also

Arjun Saha, arjungeo93@gmail.com; Ranjan Roy, royranjangeo@gmail.com | 'Department of Geography and Applied Geography, University of North Bengal, Darjeeling 734013, India. 
to sustain ecological balance, it is necessary to find out suitable areas for the new built-up development [10] and proper use of different land categories. Suitability analysis by the help of GIS platform is a process which aims to find out the best locations or areas for the proposed work while considering the ecological sustainability [4] and works according to the need of stakeholders [11]. Land suitability analysis for future urban growth is considered to be the best and effective method to find out suitable areas which works with different parameters or criteria that influence on one to settle in a place and which have some certain weightage [12]. It has become significant because this technique helps to reduce the time as well as effort to manually find out a suitable place and also filtering out the least suitable or not suitable places for the construction of new built up [13]. As this analysis is based on different criteria or alternatives and selection of criteria is based on human judgement, so it is called multi-criteria decision-making (MCDM) analysis and this MCDM analysis is capable of providing different tools for complex planning in terms of strutting priorities, weighing and selecting alternatives and also allocate resources across competing activities [14]. This MCDM can be classified into two categories, based on the number of alternatives under consideration and these are, Multi-Attribute Decision Making or MADM and Multi-Objective Decision Making or MODM [15-17]. MADM is mainly used for suitability analysis of a particular facility, and alternatives are predefined and limited in number [18] like, to find out a place for solid waste disposal [19, 20], for locating new hospitals [21], etc. But in the MODM technique, alternatives are not predefined and are numerous in number [18]. In multi-criteria decision-making technique, weight or scoring of a particular criterion plays a significant role as they provide the importance of a particular criterion [22]. To determine the weights of criteria, different models can be grouped into two and these are subjective model and objective model. In subjective approaches, decision makers or experts on that respective field give their opinion on the significance of criteria and the weights of criteria are calculated based on the information gathered from the experts or decision makers, whereas in objective methods, weights of criteria are determined based on the information contained in a decision-making matrix by applying certain mathematical models and it neglects different opinions of experts or decision makers [23]. Some well-known objective approaches are, Entropy method, Criteria Importance Through Interaction Correlation or CRITIC method, FANMA method, etc., and some best subjective methods are Decision-making Trial and Evaluation Laboratory or DEMATEL method, Step-wise Weight Assessment Ratio Analysis or SWARA method, Best Worst Method or BWM, Full Consistency Method or FUCOM, Analytic Hierarchy Method or
AHP. DEMATEL has been used in different kinds of studies $[24,25]$, but its main disadvantage is unable to validate the result, i.e. the measurement of inconsistency and for this DEMATEL method is often used to find out the weights of criteria with combination of Analytic Network Process or ANP [26] which can slightly reduce its weakness. SWARA method has also simplicity of calculation with few numbers of steps, but like the DEMATEL method, it also does not have the ability to determine the degree of consistency of the pair wise comparison [23]. In recent, AHP, BWM, LBWA and FUCOM have been increasingly applied in different works because of the ability of determining the degree of consistency. Among these methods, required number of pair wise comparison in FUCOM is minimum, because it requires only $(n-1)$ of criteria, whereas AHP requires $(n(n-1) / 2)$ criteria. But the further process of calculation in FUCOM method is complicated. BWM method requires only $(2 n-3)$ number of pairwise comparison which is more than the half number of pairwise comparison that requires in AHP and also more than the FUCOM. However, a large number of comparisons in the pairs of criteria define the limitations for solving nonlinear model make the application of the BWM significantly more complex [27]. Level-Based Weight Assessment or LBWA model also allows for the calculation of weight coefficients with a minimum number of criteria in pairwise comparison, that is $(n-1)$ as FUCOM method [27]. Another advantages of LBWA method are the algorithm does not become more complex when criteria increases and weightage values are obtained by simple mathematical calculations which eliminates inconsistencies of expert preferences, which are tolerated in BWM method [27]. Beside these advantages, this method needs to emphasize the flexibility in terms of additional corrections of weight coefficient values by the elasticity coefficient which allows decision makers to further adjustment in weight coefficient values in accordance with their own preferences. Saaty [28] proposed the Analytic Hierarchy Process or AHP to find out the weights of a particular criterion in multi-criteria analysis by pair wise comparison matrix table, and it is based on hierarchical structure, and for this each and every criterion can be focussed in a better and transparent way [16]. It is a widely used method along with GPS and remote sensing in GISbased MCA technique for proper urban land use planning and management $[18,29]$. AHP can set the criteria of land use suitability planning in a structured way based on available data, and it can standardize the criteria with simple mathematical calculations [18], and it is much easier for the social science researchers as it follows few numbers of steps to calculate weights of a criterion and does not involve any complex mathematical calculation [16]. Finally, GIS-based AHP can overlay all the standardized criteria that help to make rankings on a locational basis [18]. Based 
on these considerations, this AHP method has been chosen for this work to calculate weights of different criterion.

In recent years, Multi-Attribute Decision-Making (MADM) analysis and Analytic Hierarchy Process or AHP have been used in various literatures for the demarcation of suitable places for new built-up development. For example, Aburas et. al. [4] explained a review on different literature which deals with land suitability analysis for further urban growth by AHP and GIS techniques. They categorized all criteria into five classes and presented the whole methodology step by step. Ullah and Mansourian [18] used multi-criteria decision-making model and AHP for the evaluation of suitable land for urban land use planning. They took different factors, such as physical, accessibility and also community factors for the analysis. They also described that the justification of taking AHP method for the weightage calculation of these factors. Weldu and Deribew [30] developed a suitability map for the identification of potential sites for the housing development by using multi-criteria evaluation technique along with AHP and GIS. They took a total of ten criteria and presented the whole calculation of AHP in a lucid way. Chougale et. al. [10], Kumar and Shaikh [13] also used GIS-based multicriteria evaluation technique along with AHP method for the identification of suitable sites for the urban development and presented the whole calculations of AHP in an efficient way. For the pairwise comparison of AHP, it is necessary to calculate the weightage on the basis of information that gathered from different experts as AHP falls in the subjective model, but most of the authors have ignored this step and they put the value of Saaty's nine point scale according to their opinions. This present work has been carried out using AHP method and has been followed the decisions that have been put by the experts.

This work has been carried out in Siliguri which has witnessed a tremendous growth in built-up features due to huge migration in the partition time and after the partition it got its importance due to its location as it serves as a transit point for the entire north eastern part of the country and some neighbouring countries and also as an important economic centre. For this, this city attracts population from different states for last four decades. According to census of India, 2001 as a total of 139,418 persons from 1991 to 2001 have migrated from different states and districts of West Bengal which was 106,098 from 1981 to 1991 (Census of India, 1991, 2001, Migration table, D series data). This huge growth of population give rises to unplanned built-up growth in and around the city and transforms different productive land into built-up and impervious land which need immediate actions to control this unscientific and haphazard growth. No such work to overcome this problem and also to identify the best locations for scientifically built-up development has not been carried out for this area. So, for the sustainable urban development or built-up growth, it is needed to improve the current pattern and for this reason, and major thrust or aim of this work has been given to find out best places for the built-up development with the minimum effects on different natural features using GIS-based multi-criteria analysis and analytic hierarchy process in and around the city Siliguri (Fig. 1). This work has been done with the consultation of different experts who are responsible for this type of developmental works and based on their advices and thinking, and this work has been preceded further which is a novelty of this work. This work also calculates the amount of different types of suitability which will be transformed from different land use and land cover categories in near future. At last, the calculated result of highly and moderate suitable places has been verified by physically. The whole paper has been arranged in a following way. At first, criteria have been chosen and for the criteria weight, AHP method has been followed in where pair wise comparison table has been filled up with the consultation of experts. Data for each criterion map have been collected from different repositories and prepared in GIS platform, and then calculated weights have been assigned in each criterion map. Final suitability map has been prepared by integrating all criteria maps by using weighted overlay tool in GIS platform (Fig. 2).

\section{Study area}

Siliguri, one of the most rapidly developing and fastest growing metropolis, is located in the northern part of West Bengal and foothills of Darjeeling Himalaya. It was a small village with less than 800 populations in 1901 and turned into a municipality town in 1949 with a population of 32,480 . It is because of the partition of India after independence and huge in-migration from the Bangladesh (erstwhile East Pakistan), Nepal, southern parts of Bhutan and adjacent states of it. Due to different developmental projects and business activities, it increases its population by natural way and by pulling from neighbouring areas; it got a status of Municipal Corporation in the year 1994. In the year 1980, Siliguri Jalpaiguri Development Authority (SJDA) was set up by the government of West Bengal with an aim of planning and development in Siliguri and Jalpaiguri planning area. Due to rapid growth of population and built-up area that have been experienced by Siliguri after 1980, a need for the control of growth and proper land use was felt by the authority and for this Outer Development Planning Area (ODPA) was formed in the year 1992 for three separate area, Siliguri, Jalpaiguri and Naxalbari; but from the year 2001, this ODPA term has changed and a new term Land Use and Development Control Plan or 


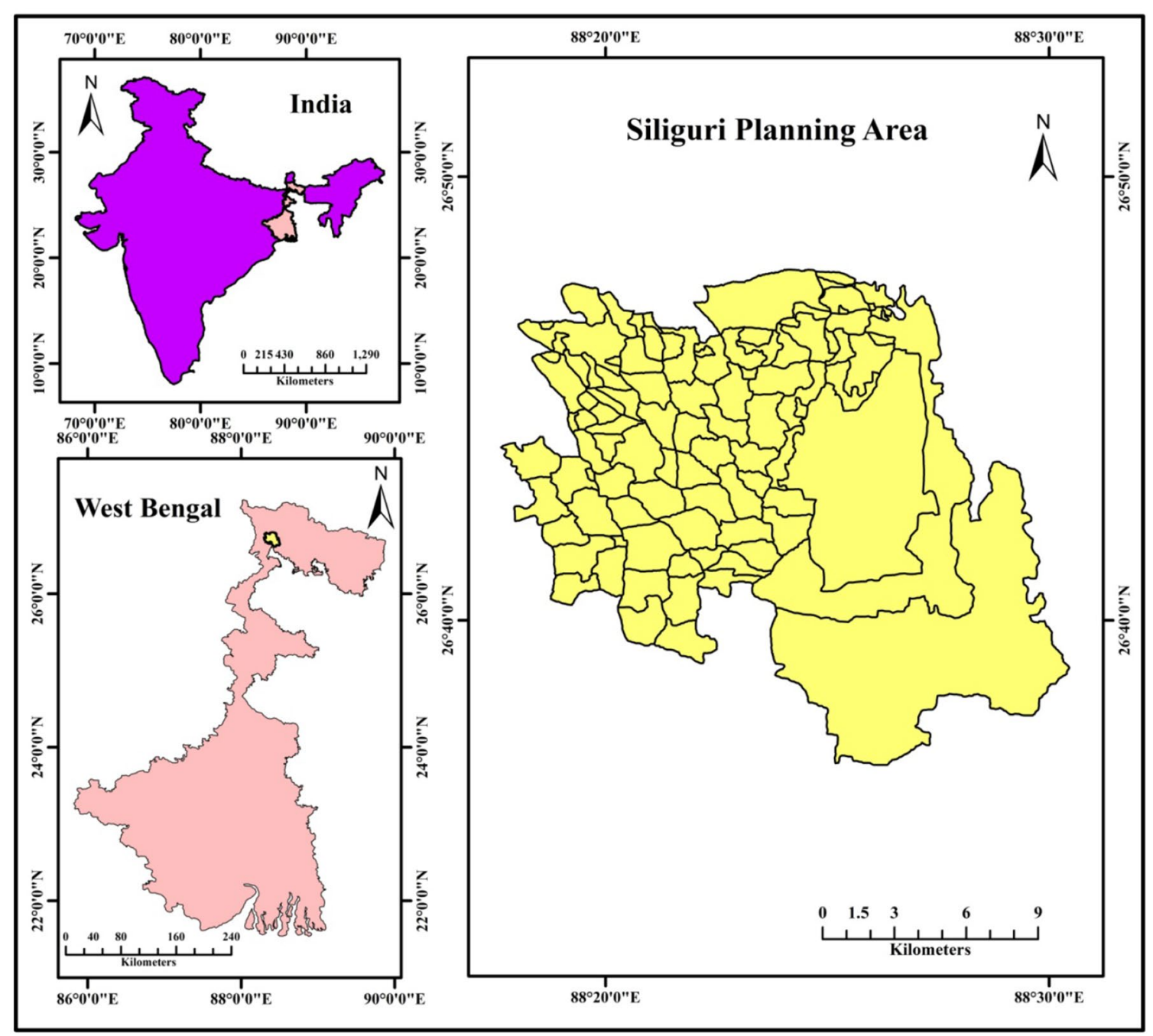

Fig. 1 Location map of the Siliguri planning area

LUDCP has introduced. Out of these three LUDCP or planning area, Siliguri Planning Area has been selected for this work as this area has witnessed huge changes in built-up pattern, which are not in a proper planned way. At present, this area covers Siliguri Municipal Corporation, twelve census towns and eighty eight villages with a total population of 963,498 .

\section{Methods}

\subsection{Selection of criteria}

Appropriate and significant criteria selection is the first step to calculate the suitable area properly for any purpose though the final selection of criteria also depends on the availability of data [4]. Selection of criteria for the suitable area of built-up growth varies from researcher to researcher, yet all the criteria can be grouped into four major factors, i.e. accessibility, physical, socio-economic and environmental factor. Table 1 shows the factors and criteria that are used by different researchers in previous studies and based on this table and also synthesizing different literatures $[11,12,18,30]$ most significant and frequent used criteria have been taken for this work.

Accessibility and physical factors are most determining factors followed by environmental and socio-economic factors as these have been used by maximum researchers. Three accessibility factors (distance from road, distance from airport and distance from railway station), three environmental factors (land use land cover types, distance from river and distance from canal), two physical factors (slope and geological formation) and one socioeconomic factor (population density) have been taken in this work for the identification of suitable site for built-up growth (Table 2). 


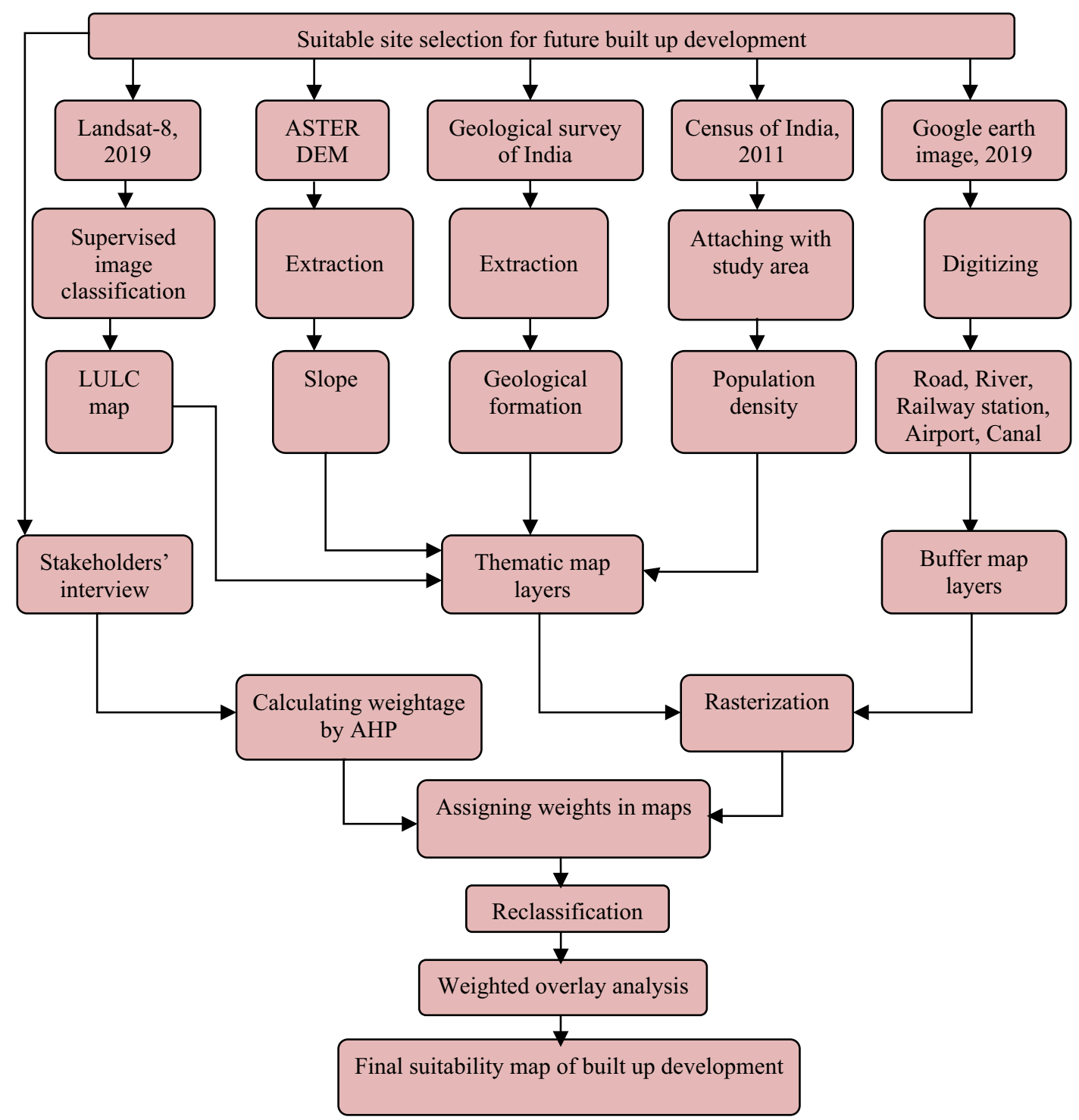

Fig. 2 Step-wise flow chart of GIS-AHP-based methodology to identify suitable places for built-up development

Table 1 Different criteria used for urban site selection studies

\begin{tabular}{lllll}
\hline Factors & Accessibility & Physical & Socio-economic & Environmental \\
\hline $\begin{array}{l}\text { Criteria } \\
\text { References }\end{array}$ & $\begin{array}{c}\text { Distance from road, Distance from } \\
\text { airport, Distance from railway sta- } \\
\text { tion, etc }\end{array}$ & $\begin{array}{c}\text { Slope, Geol- } \\
\text { ogy, Eleva- } \\
\text { tion, etc }\end{array}$ & $\begin{array}{l}\text { Population density, } \\
\text { Distance from economic } \\
\text { centres, etc }\end{array}$ & $\begin{array}{c}\text { LULC, Distance from river, Distance from } \\
\text { canal, Distance from ponds or lakes, } \\
\text { Soil types, etc }\end{array}$ \\
{$[31]$} & $\bullet$ & $\bullet$ & $\bullet$ & $\bullet$ \\
{$[32]$} & $\bullet$ & $\bullet$ & $\bullet$ & $\bullet$ \\
{$[13]$} & $\bullet$ & $\bullet$ & $\bullet$ & $\bullet$ \\
{$[33]$} & $\bullet$ & $\bullet$ & $\bullet$ & $\bullet$ \\
{$[35]$} & $\bullet$ & $\bullet$ & $\bullet$ & $\bullet$ \\
{$[36]$} & $\bullet$ & $\bullet$ & & $\bullet$ \\
\hline$[37]$ & $\bullet$ & & $\bullet$ & $\bullet$
\end{tabular}




\subsection{Calculating weightage by AHP}

AHP or Analytic Hierarchy Process is a well-known and universally used subjective method to determine weights of criteria in multi-criteria decision-making technique [22]. It can be used to find out weights for qualitative as well as qualitative data [40]. It is based on questionnaire survey by expert. Two of them are professor and assistant professor of university and specialized in urban geography and regional planning and they have the experience of doing different future prospective projects for this area under the Siliguri Jalpaiguri Development Authority, one is real estate developer, who already have done several projects related to apartments and housing complexes, and rest two are local people who want to buy residential houses in this region. They are asked to give a score on the basis of Saaty's 1 to 9 ratio scale [38] through pair wise comparison.
The comparison between two criteria is made by judgement of an expert that represents how much more one criterion influences over another [11]. If two criteria influence same or have equal importance, a score of 1 have to give and a score of 9 is given when the influence of one criterion is extreme over another criterion in the comparison table [22]. After normalizing each value by dividing the actual value to its sum of column value, weights are derived by arithmetic mean method (Table 3 ).

After calculating weights, it is necessary to calculate consistency ratio (CR) to check the degree of consistency of judgements that has made by any expert [30]. Saaty [41] has provided an index to justify that the comparison matrix is consistent or not. The formula of getting CR value is,

$\mathrm{CR}=\mathrm{Cl} / \mathrm{RI} * 100$

Table 2 Selected criteria and sources of data

\begin{tabular}{lllll}
\hline Factors & Criteria & Data & Source & Type of data \\
\hline Accessibility & Distance from road & Google earth spatial & Google earth & Spatial vector data \\
& Distance from railway station & Google earth spatial & Google earth & Spatial vector data \\
& Distance from airport & Google earth spatial & Google earth & Spatial vector data \\
Environmental & LULC & Landsat OLI-TIRS, 2019 & USGS earth explorer & Spatial raster grid data \\
& Distance from river & Google earth spatial & Google earth & Spatial vector data \\
& Distance from canal & Google earth spatial & Google earth & Spatial vector data \\
Physical & Slope & ASTER Digital Elevation Model & NASA earth data & Spatial raster grid data \\
& Geological formation & Geology 50 K & Geological survey of India & Spatial vector data \\
Socio-economic & Population density & Population census & Census of India & Attribute data \\
\hline
\end{tabular}

Table 3 The fundamental scale of absolute numbers for AHP. [38] Source: Saaty, T.L.

\begin{tabular}{|c|c|c|}
\hline Intensity of importance & Definition & Explanation \\
\hline 1 & Equal importance & Two activities contribute equally to the objective \\
\hline 2 & Weak or slight importance & \\
\hline 3 & Moderate importance & $\begin{array}{l}\text { Experience and judgement slightly favour one activity } \\
\text { over another }\end{array}$ \\
\hline 4 & Moderate plus & \\
\hline 5 & Strong importance & $\begin{array}{l}\text { Experience and judgement strongly favour one activity } \\
\text { over another }\end{array}$ \\
\hline 6 & Strong plus & \\
\hline 7 & Very strong to demonstrated importance & $\begin{array}{l}\text { An activity is favoured very strongly over another, its } \\
\text { dominance demonstrated in practice }\end{array}$ \\
\hline 8 & Very, very strong & \\
\hline 9 & Extreme importance & $\begin{array}{l}\text { The evidence favouring one activity over another is of } \\
\text { the highest possible order of affirmation }\end{array}$ \\
\hline Reciprocals of above & $\begin{array}{l}\text { If activity } i \text { has one of the above nonzero numbers } \\
\text { assigned to it when compared with activity } j \text {, then } j \\
\text { has the reciprocal value when compared with } i\end{array}$ & A reasonable assumption \\
\hline Rationals & Ratio arising from the scale & $\begin{array}{l}\text { If consistency were to be forced by obtaining } n \text { numeri- } \\
\text { cal values to span the matrix }\end{array}$ \\
\hline
\end{tabular}


Table 4 The random inconsistency value. [39]

Source: Saaty, T.L.

\begin{tabular}{lllllllllll}
\hline Number of criterion & 1 & 2 & 3 & 4 & 5 & 6 & 7 & 8 & 9 & 10 \\
\hline Random Inconsistency & 0.00 & 0.00 & 0.58 & 0.90 & 1.12 & 1.24 & 1.32 & 1.41 & 1.45 & 1.49
\end{tabular}

where, $\mathrm{CR}$ is the consistency ratio, $\mathrm{Cl}$ is the ratio of consistency index and $\mathrm{Rl}$ is the random inconsistency index of randomly generated pair wise comparison matrix of order 1 to 10 calculated by approximating random indices using a sample of 500 [39]. In the formula of consistency ratio $(\mathrm{CR}), \mathrm{Cl}$ is calculated by the following equation.

$\mathrm{Cl}=(\lambda-n) /(n-1)$

where, $\mathrm{Cl}$ is the consistency index, $\lambda$ is simply the average of consistency vector, $\mathrm{n}$ refers to the number of total criteria.

The consistency ratio has been designed in such a way that, if the value is $<10 \%$, then the matrix is said to be a sufficiently consistent and the matrix is accepted, but if it is more than $10 \%$, then it is an indication of inconsistent judgement (Table 4).

\subsection{Preparing criteria maps}

After selecting criteria for suitable site of future urban area, different thematic maps have been prepared. Total nine thematic maps have been prepared in a GIS platform as the selected criteria are nine which are mostly in vector data format.

\subsection{Rasterization of criteria maps}

As the mostly maps are in a vector data format, so it is the next step to convert the format of vector maps into raster for further analysis.

\subsection{Integration of criteria maps and final suitability map}

After converting into raster data format and assigning weights, these criteria maps are then integrated by using weighted overlay tool in GIS platform to get the final suitability map of future urban development.

\section{Results and discussion}

As almost all the cities in developing countries are expanding haphazardly, so the identification of suitable sites for proper sustainable urban growth has become a fundamental and important work for these cities. The further analysis for suitable site has been carried out by using nine parameters, and the amalgamation of these nine criteria has helped to find out different suitable places for future built up.

\subsection{Accessibility factor}

Smooth and efficient movement and better connectivity with the entire city and other places are the prime need for an individual to set up new construction either for residence or commercial purposes. In this regard, proximity to road and railway play an important role though proximity to airport also influences people who frequent use this service. Construction of new road is expensive, and government provides new roads to a place which has an ample number of settlements, so people wants to settle in a place which has already better road connectivity. Similarly as the number of railway stations, metro stations, airports in a city are fixed, so people tend to set up their dwellings or commercial unit close to these facilities for easily accessible.

In this work, to find out the accessibility in the entire area, major roads like, Asian highway, national highways, state highways and important village and municipal roads which are more than 15 feet width and has connection with different places, six railway stations and one airport have been digitized from the Google earth.

Now to find out better accessibility and also to find out the best locations to the existing roads, railway stations and airport, buffer zone maps by taking $250 \mathrm{~m}$ as interval has been prepared (Fig. 3) and their importance for builtup growth has been identified by ranking.

\subsection{Environmental factors}

Environmental factors play a significant role for identifying suitable places for any developmental work. Though it is not possible all the time, but mostly all the constructional projects have been implemented by preserving the natural environment. In this work, three environmental factors, such as, land use land cover types, distance from river and distance from canal, have taken to identify the suitable places.

Land use land cover map has been prepared from the Landsat 8 data of the year 2019. It has been categorized into built-up land, water bodies, vegetation, agricultural land and wasteland based on NRSA manual, 2006. In the further analysis, existing built-up land has been considered as restricted category because no such new 

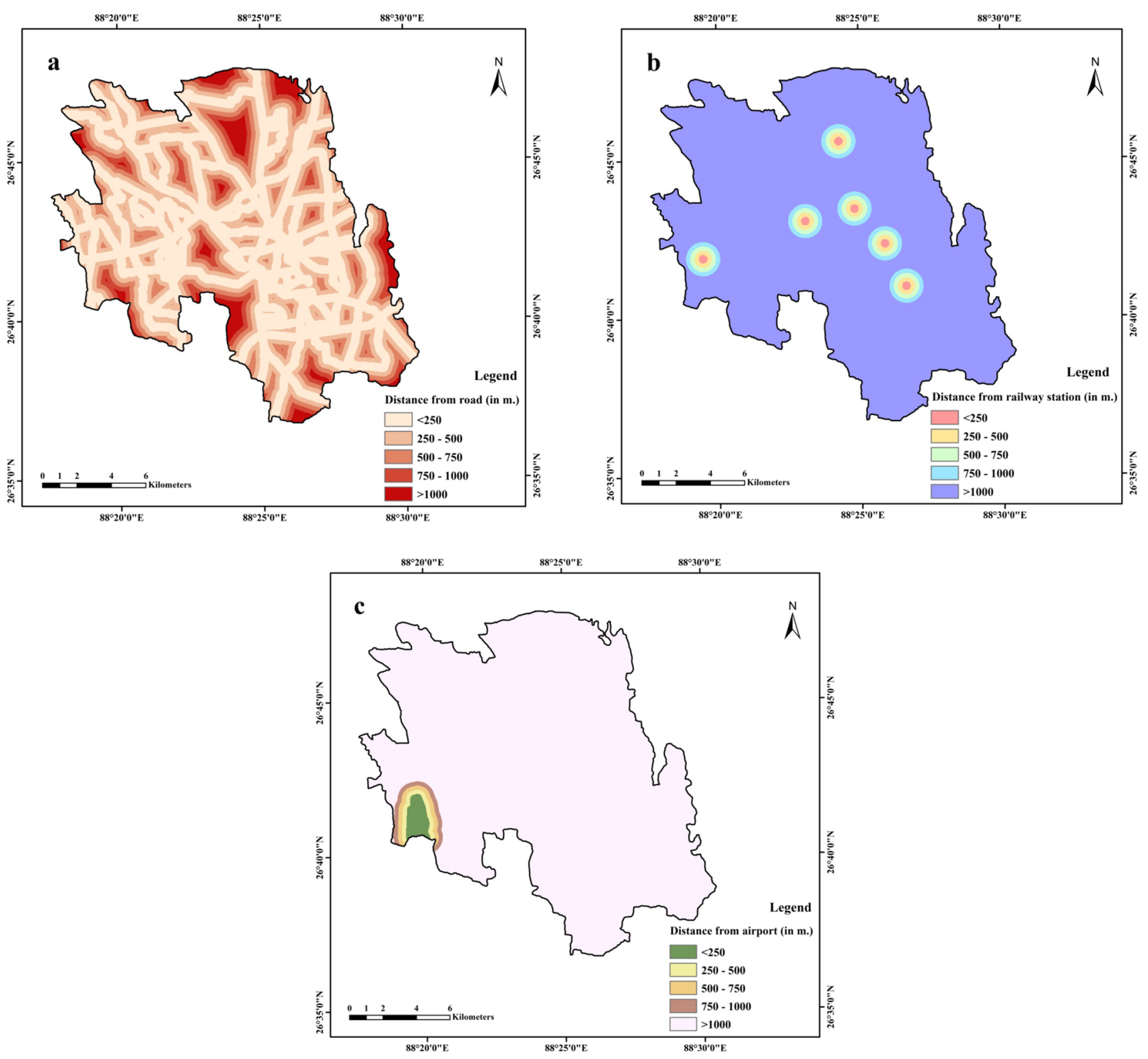

Fig. 3 Accessibility factors for identifying suitable sites of urban growth. a. Distance from roads, b. Distance from railway stations, c. Distance from airport

construction can be done in future, though vertical growth can take place but this work mainly tries to find out the places which are vacant. Similarly, water bodies are also categorized as restricted land, whereas wasteland and agricultural land have been given the priority for locating suitable places of built up.

Siliguri and the surrounding study area lie in the piedmont of Darjeeling Himalaya, so the numbers of rivers are naturally more and are perennial in character. This area also receives huge rainfall during the monsoon, which makes these rivers more furious, but the possibility of occurrence of flood is less in here because this area located in the piedmont region with an average height of $150 \mathrm{~m}$. Two major rivers Mahananda and Balason are flowing through this area. For identifying the best location, buffer zones have created with an interval of $250 \mathrm{~m}$ from existing water bodies with a ranking from 1 to 5 . The area which are just beside the river ranked as 5 which means very less suitable, and the area located beyond $1000 \mathrm{~m}$ ranked as 1 means very high suitable because people wants to reside in a relatively higher area with a minimum distance from river to avoid the flood problem. Similar ranking pattern 

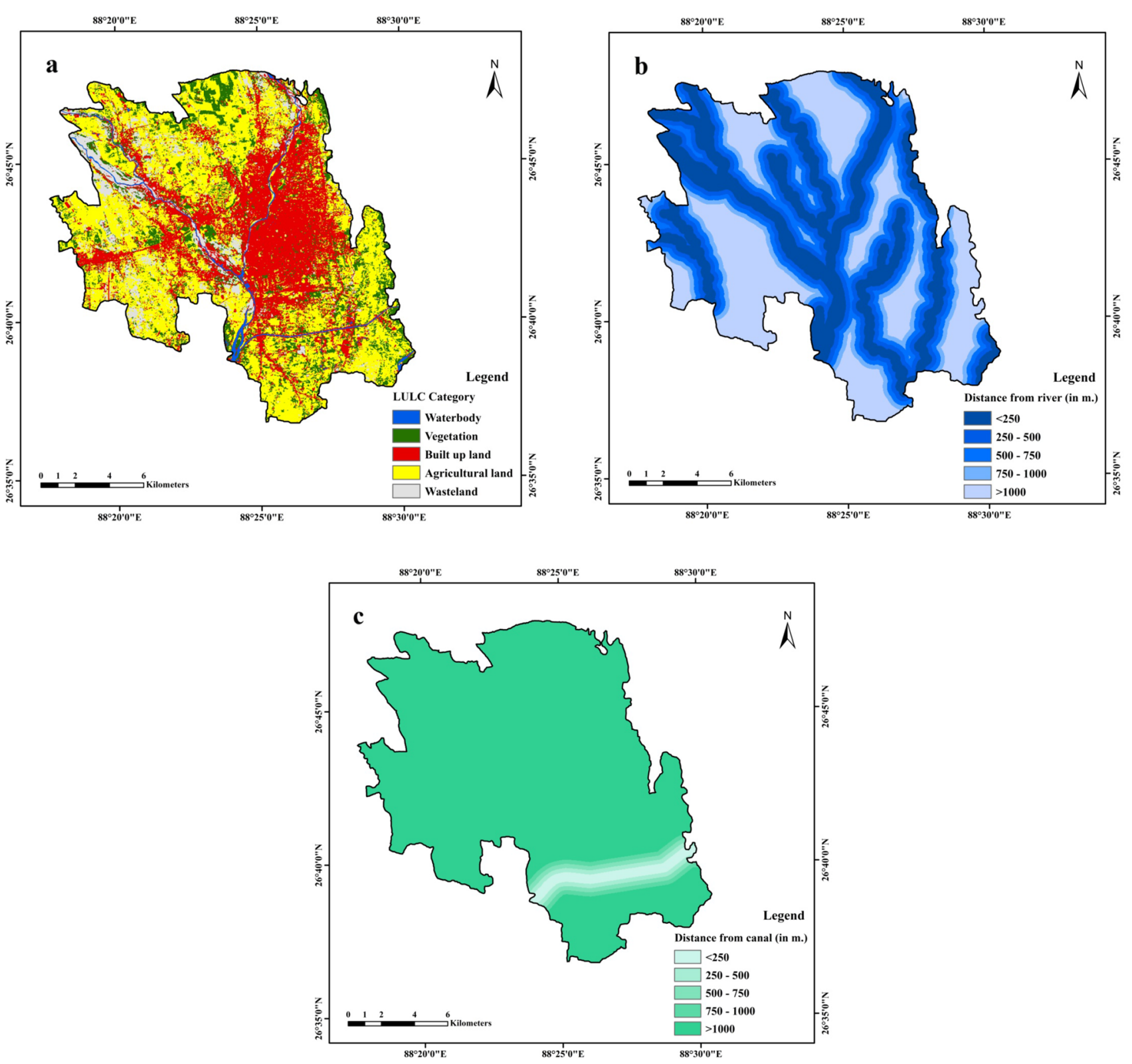

Fig. 4 Environmental factors for identifying suitable sites of urban growth. a. Land use land cover map, b. Distance from rivers, c. Distance from canal

has assigned to the layers of canal map, which is located to the southern part of the study area (Fig. 4).

\subsection{Physical factors}

Physical factors, like elevation and slope, are the basic parameters for setting up settlements mainly in the hilly terrain. Steep slope lands are not suitable for any kind of construction because it needs more construction costs and also risky. Therefore, gentle slopes are suitable for construction. Though in plain region these parameters have negligible influences on constructing new built up. For the major built-up projects like, shopping malls, hotels, townships, high rise buildings and flats, geological set up of that area should be examined properly and it is necessary for this study area because this area falls in the high risk zone of earthquake according to the seismic zones of India and this area has shown a tremendous growth in high rise buildings, townships and shopping malls.

The whole study area has been categorized into five slope zones starting from less than 10 to more than 25 . Classified map of slope shows that, maximum area falls in the less than 10 slope zone, whereas only banks of the river show more than 25 slope zone. Less than 10 slope 

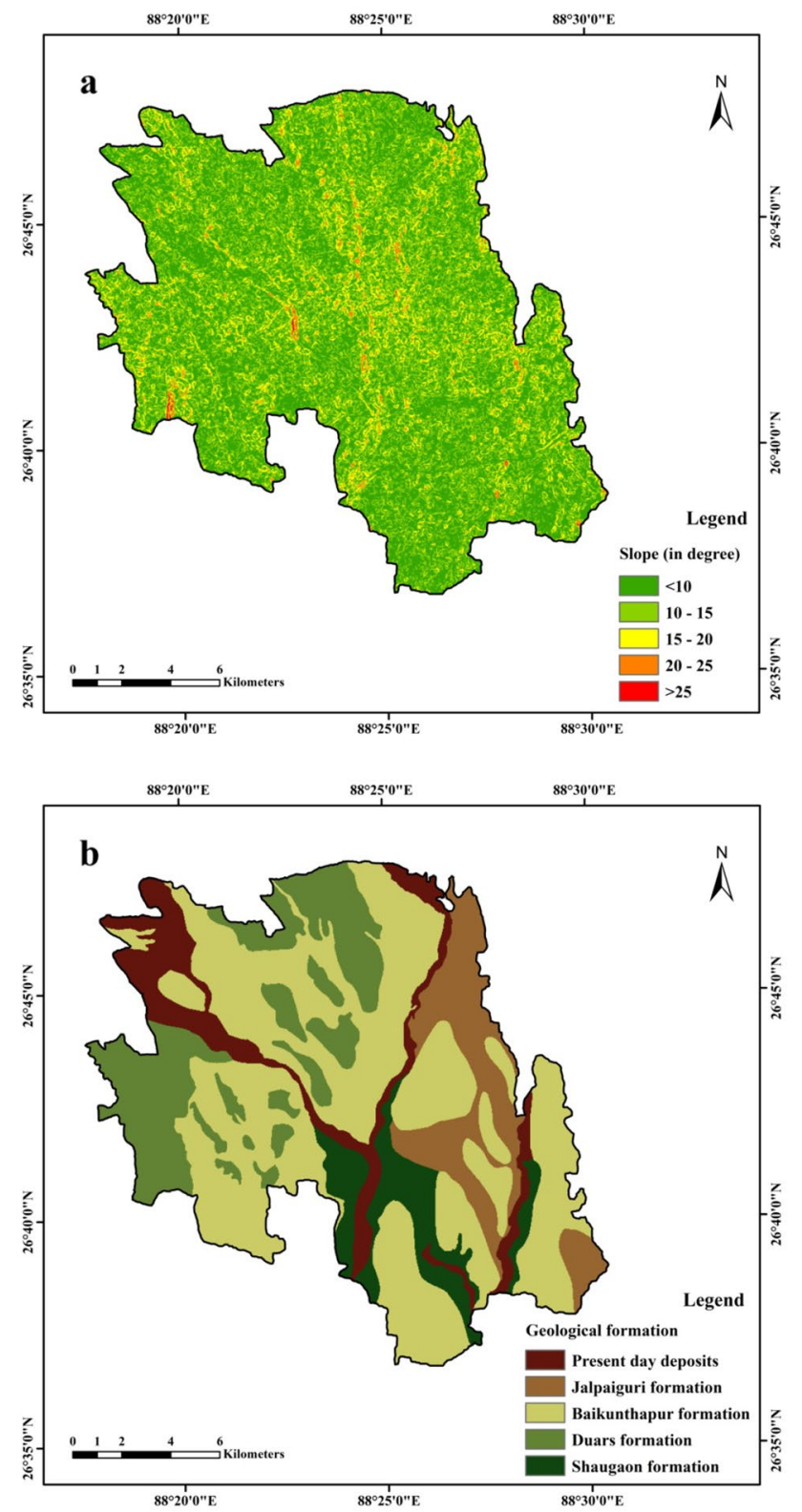

Fig. 5 Physical factors for identifying suitable sites of urban growth, a. Slope map, b. Geological formation

zone are considered as gentle slope [42], and it is more suitable for the new construction. So this category has been assigned as rank 1 means very high suitable and more than 25 as 5 means very less suitable. Geological data have been collected from Geological Survey of India which defines that five types of formation have been seen in this area and these are Present day deposits, Jalpaiguri formation, Baikunthapur formation, Duars formation and Shaugaon formation. Baikunthapur formation has covered the most portion of this area, and it consists of very fine white sand inter layered with silty clay and overlain by dark grey to thick silty loam which is ideal for new construction and for this it has been ranked as 1, whereas present day deposits are the youngest formation and mainly found in the river bed consists of sediments which is not suitable for the construction of new built up and hence, it is ranked as 5 means unsuitable (Fig. 5).

\subsection{Socio-economic factors}

Human being always finds a place to reside which is socially favourable for them. Most of the time, same social group of people resides closely to each other for the similarity of culture. But it cannot be possible all the time in rapidly growing cities. In these type of cities, maximum people wants to buy a plot at a cheaper rate which mostly lies away from the city core, whereas few people wants to buy in the city for any price to avail the civic facilities. But for the overall people, it can be said that, land price is a determinant factor to set up new construction of housing. Beside these, population density, housing density are also important factors which play a significant role in new built-up development, because most of the people wants to settle in a low or medium dense area than in a clumsy environment.

This study area shows a huge growth of population in last two decades. It was 510,137 in the year 1991 which has turned to almost double in the year 2011, that is 963498 according to Census of India, 2011. Administrative unit wise population density varies from 44 persons per sq. $\mathrm{km}$. in Tarabarir chat to 16,394 persons in Matigarahat, whereas household density ranges from 13 houses per sq. $\mathrm{km}$. to 3112 houses which defines a huge variation and unbalanced distribution of built up in the entire area. For this work, the whole area is divided into five groups by population density (Fig. 6) which starts from less than 1000 persons to more than 4000 persons. As most people wants to reside in a low dense area, so less than 1000 category has been assigned as rank 1 means very high suitable and more than 4000 as rank 5 means very less suitable for creating new built up (Fig. 6).

\subsection{Pair wise comparison matrix and normalized pair wise comparison matrix}

As we have taken nine criteria for the analysis, so, a total of 36 questions have been formed in the questionnaire. Then, the questionnaires have been filled up by five aforesaid experts following Saaty's 9 point scale. Most appropriate view has been taken for the further analysis. In the pair wise comparison matrix table, 81 boxes are there and we have filled up 36 boxes according to the value that we get from the questionnaire. Diagonal value always will be 1 because the influence between the same criteria will 


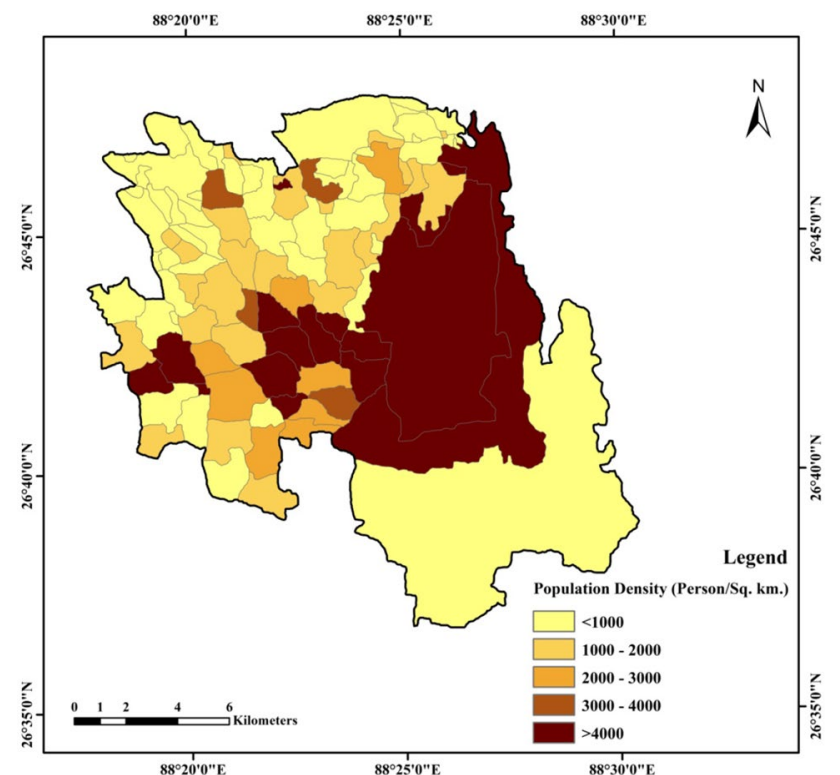

be equal. Rests are then filled up by reciprocal value of respective main value (Table 5 ).

Normalized pair wise comparison matrix table is the second step after pair wise matrix table to get the final weightage of each criterion. Normalized value has been calculated by dividing each value of pair wise matrix table with their respective total column value. Then to find out weight of each criterion, arithmetic mean method has been used row wise (Table 6). Road is the highest influencing criterion as the weightage value is $29.7 \%$ followed by airport (18.6\%), railway station (13.5\%) and land use land cover (13.2\%), whereas geology has the least influence over people to set up their dwellings as it has scored only $1.7 \%$ weightage. It is also clear from the normalized pair wise matrix table that, accessibility factor is the significant in the decision making of new built-up construction (Table 6).

Fig. 6 Population density map for identifying suitable sites of urban growth

Table 5 Pair wise comparison matrix by AHP
Table 6 Normalized pair wise comparison matrix and computation of criterion weightage

\begin{tabular}{|c|c|c|c|c|c|c|c|c|c|}
\hline \multicolumn{10}{|c|}{ Pair wise comparison matrix } \\
\hline Criteria & LULC & PD & RV & $\mathrm{RD}$ & RS & AP & $\mathrm{SP}$ & GF & $\mathrm{CN}$ \\
\hline LULC & 1 & 2 & 4 & 0.50 & 0.50 & 0.50 & 5 & 6 & 5 \\
\hline PD & 0.50 & 1 & 4 & 0.33 & 0.50 & 0.50 & 4 & 7 & 6 \\
\hline RV & 0.25 & 0.25 & 1 & 0.14 & 0.25 & 0.17 & 2 & 5 & 0.50 \\
\hline $\mathrm{RD}$ & 2 & 3 & 7 & 1 & 4 & 3 & 8 & 7 & 7 \\
\hline RS & 2 & 2 & 4 & 0.25 & 1 & 0.33 & 4 & 7 & 4 \\
\hline AP & 2 & 2 & 6 & 0.33 & 3 & 1 & 4 & 6 & 5 \\
\hline SP & 0.20 & 0.25 & 0.50 & 0.13 & 0.25 & 0.25 & 1 & 4 & 5 \\
\hline $\mathrm{GL}$ & 0.17 & 0.14 & 0.20 & 0.14 & 0.14 & 0.17 & 0.25 & 1 & 0.25 \\
\hline $\mathrm{CN}$ & 0.20 & 0.17 & 2 & 0.14 & 0.25 & 0.20 & 0.20 & 4 & 1 \\
\hline Sum & 8.32 & 10.81 & 28.70 & 2.97 & 9.89 & 6.12 & 28.45 & 47 & 33.75 \\
\hline
\end{tabular}

LULC Land use land cover, PD Population density, RV River, RD Road, RS Railway station, AP Airport, SP Slope, GF Geological formation, CN Canal

\begin{tabular}{|c|c|c|c|c|c|c|c|c|c|c|c|}
\hline \multicolumn{10}{|c|}{ Normalized pair wise comparison matrix } & \multirow[t]{2}{*}{ Criterion weights } & \multirow[t]{2}{*}{ Rank } \\
\hline Criteria & LULC & PD & $\mathrm{RV}$ & $\mathrm{RD}$ & RS & AP & SP & GF & $\mathrm{CN}$ & & \\
\hline LULC & 0.12 & 0.19 & 0.14 & 0.17 & 0.05 & 0.08 & 0.18 & 0.13 & 0.15 & 0.132 & 4 \\
\hline PD & 0.06 & 0.09 & 0.14 & 0.11 & 0.05 & 0.08 & 0.14 & 0.15 & 0.18 & 0.110 & 5 \\
\hline RV & 0.03 & 0.02 & 0.03 & 0.05 & 0.03 & 0.03 & 0.07 & 0.11 & 0.01 & 0.040 & 7 \\
\hline $\mathrm{RD}$ & 0.24 & 0.28 & 0.24 & 0.34 & 0.40 & 0.49 & 0.28 & 0.15 & 0.21 & 0.297 & 1 \\
\hline RS & 0.24 & 0.19 & 0.14 & 0.08 & 0.10 & 0.05 & 0.14 & 0.15 & 0.12 & 0.135 & 3 \\
\hline AP & 0.24 & 0.19 & 0.21 & 0.11 & 0.30 & 0.16 & 0.14 & 0.13 & 0.15 & 0.186 & 2 \\
\hline SP & 0.02 & 0.02 & 0.02 & 0.04 & 0.03 & 0.04 & 0.04 & 0.09 & 0.15 & 0.048 & 6 \\
\hline GL & 0.02 & 0.01 & 0.01 & 0.05 & 0.01 & 0.03 & 0.01 & 0.02 & 0.01 & 0.017 & 9 \\
\hline $\mathrm{CN}$ & 0.02 & 0.02 & 0.07 & 0.05 & 0.03 & 0.03 & 0.01 & 0.09 & 0.03 & 0.035 & 8 \\
\hline Sum & 1 & 1 & 1 & 1 & 1 & 1 & 1 & 1 & 1 & & \\
\hline
\end{tabular}

LULC Land use land cover, $P D$ Population density, RV River, $R D$ Road, $R S$ Railway station, $A P$ Airport, $S P$ Slope, GF Geological formation, CN Canal 


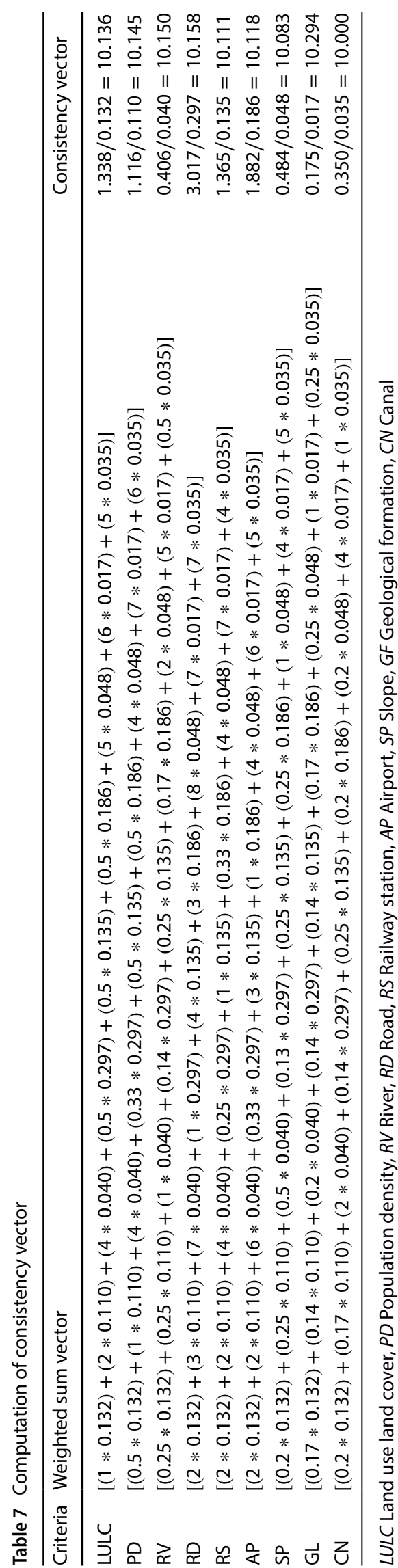

\subsection{Calculation of the consistency ratio}

It is necessary to check the degree of consistency of the judgements. Before going to calculate the value of $C R$, the value of consistency index $(\mathrm{Cl})$ and $\lambda$ should be calculated. Table 7 shows the calculation of consistency vector. Calculation of lambda

$C l=(\lambda-n) /(n-1)=(10.13-9) /(9-1)=0.14$

$C R=C l / R I * 100=0.14 / 1.45 * 100=9.82 \%$

The result of consistency ratio (CR) is less than $10 \%$, so it can be said that the judgement is consistent and it is allowed for the further analysis.

\subsection{Analysing final suitability map}

After calculating final weights of each criterion and preparing thematic and buffer maps in GIS platform, all map layers except land use land cover and slope map are then converted to raster data format by using conversion tool for further suitability analysis. These maps are then integrated, and reclassification of the sub-layers of each map has been done as reclassification tool is employed to convert 5on a scale [43] for land suitability (Table 8), and using weighted overlay analysis tool, suitable sites for future built-up development have been delineated. Final suitability map has been classified into four groups, restricted or not suitable, highly suitable, moderate suitable and less suitable. Table 9 shows the area that has fallen in each zone of suitability. About $31 \%$ area that falls on restricted zone means no such new construction can be done in this zone which comprises existing built-up land and water bodies. Highly suitable zone is relatively less among different zones, which is only $1.76 \%$ or 4.58 $\mathrm{sq}$. $\mathrm{km}$. because a little amount of land has fulfilled entire criteria which also demonstrate that this area is now at best position by its available built-up features. Further construction in this area will harm the productive features like agricultural land, planted vegetated area mainly tea plantation area because this entire area is mostly dominated by moderate suitable zone for built-up development, and this category mostly covered by agricultural land. It can be predicted that if this present trends of growth of population and built-up continue, then in future maximum portion of agricultural land, mainly tea planted area will be vanished. Major roads are relatively less than the requirement and railway stations also few in number and not distributed equally to the entire region, which is also a reason for having less amount of highly suitable area and high amount of moderate suitable area. Maximum villages of Bagdogra area have shown highly and moderate suitable 
Table 8 Summary of criteria, sub-criteria, suitability level, ranking of sub-criteria and weightage of criteria

\begin{tabular}{|c|c|c|c|c|}
\hline Criteria & Sub-criteria & Level of suitability & Ranking & $\begin{array}{l}\text { Weightage } \\
\text { in percent- } \\
\text { age }\end{array}$ \\
\hline \multirow[t]{5}{*}{ Distance from road } & $<250 \mathrm{~m}$ & Very high & 1 & 29.7 \\
\hline & $250 m-500 m$ & High & 2 & \\
\hline & $500 m-750 m$ & Moderate & 3 & \\
\hline & $750 m-1000 m$ & Less & 4 & \\
\hline & $>1000 \mathrm{~m}$ & Very less & 5 & \\
\hline \multirow[t]{5}{*}{ Distance from airport } & $<250 \mathrm{~m}$ & Very less & 5 & 18.6 \\
\hline & $250 m-500 m$ & Less & 4 & \\
\hline & $500 m-750 m$ & Moderate & 3 & \\
\hline & $750 m-1000 m$ & Very high & 1 & \\
\hline & $>1000 \mathrm{~m}$ & High & 2 & \\
\hline \multirow[t]{5}{*}{ Distance from railway station } & $<250 \mathrm{~m}$ & Very less & 5 & 13.5 \\
\hline & $250 m-500 m$ & Moderate & 3 & \\
\hline & $500 m-750 m$ & High & 2 & \\
\hline & $750 m-1000 m$ & Very high & 1 & \\
\hline & $>1000 \mathrm{~m}$ & Less & 4 & \\
\hline \multirow[t]{5}{*}{ Land use land cover } & Waste land & Very high & 1 & 13.2 \\
\hline & Agricultural land & High & 2 & \\
\hline & Vegetation & Moderate & 3 & \\
\hline & Built-up land & Restricted & 0 & \\
\hline & Water bodies & Restricted & 0 & \\
\hline \multirow[t]{5}{*}{ Population density } & $<1000$ & Very high & 1 & 11.0 \\
\hline & $1000-2000$ & High & 2 & \\
\hline & $2000-3000$ & Moderate & 3 & \\
\hline & $3000-4000$ & Less & 4 & \\
\hline & $>4000$ & Very less & 5 & \\
\hline \multirow[t]{5}{*}{ Slope } & $<10^{\circ}$ & Very high & 1 & 4.8 \\
\hline & $10^{\circ}-15^{\circ}$ & High & 2 & \\
\hline & $15^{\circ}-20^{\circ}$ & Moderate & 3 & \\
\hline & $20^{\circ}-25^{\circ}$ & Less & 4 & \\
\hline & $>25^{\circ}$ & Very less & 5 & \\
\hline \multirow[t]{5}{*}{ Distance from river } & $<250 \mathrm{~m}$ & Very less & 5 & 4.0 \\
\hline & $250 m-500 m$ & Less & 4 & \\
\hline & $500 m-750 m$ & Moderate & 3 & \\
\hline & $750 m-1000 m$ & High & 2 & \\
\hline & $>1000 \mathrm{~m}$ & Very high & 1 & \\
\hline \multirow[t]{5}{*}{ Distance from canal } & $<250 \mathrm{~m}$ & Very less & 5 & 3.5 \\
\hline & $250 m-500 m$ & Less & 4 & \\
\hline & $500 m-750 m$ & Moderate & 3 & \\
\hline & $750 m-1000 m$ & High & 2 & \\
\hline & $>1000 \mathrm{~m}$ & Very high & 1 & \\
\hline \multirow[t]{5}{*}{ Geological formation } & Baikunthapur & Very high & 1 & 1.7 \\
\hline & Duars & High & 2 & \\
\hline & Jalpaiguri & Moderate & 3 & \\
\hline & Shaugaon & Less & 4 & \\
\hline & Present day deposits & Very less & 5 & \\
\hline
\end{tabular}


Table 9 Different suitability categories and their area

\begin{tabular}{lcc}
\hline Suitability categories & Area in sq. km & $\begin{array}{l}\text { Area in } \\
\text { percent- } \\
\text { age }\end{array}$ \\
\hline Restricted or Not suitable & 80.89 & 31.00 \\
Highly suitable & 4.58 & 1.76 \\
Moderate suitable & 136.56 & 52.33 \\
Less suitable & 38.93 & 14.91 \\
\hline
\end{tabular}

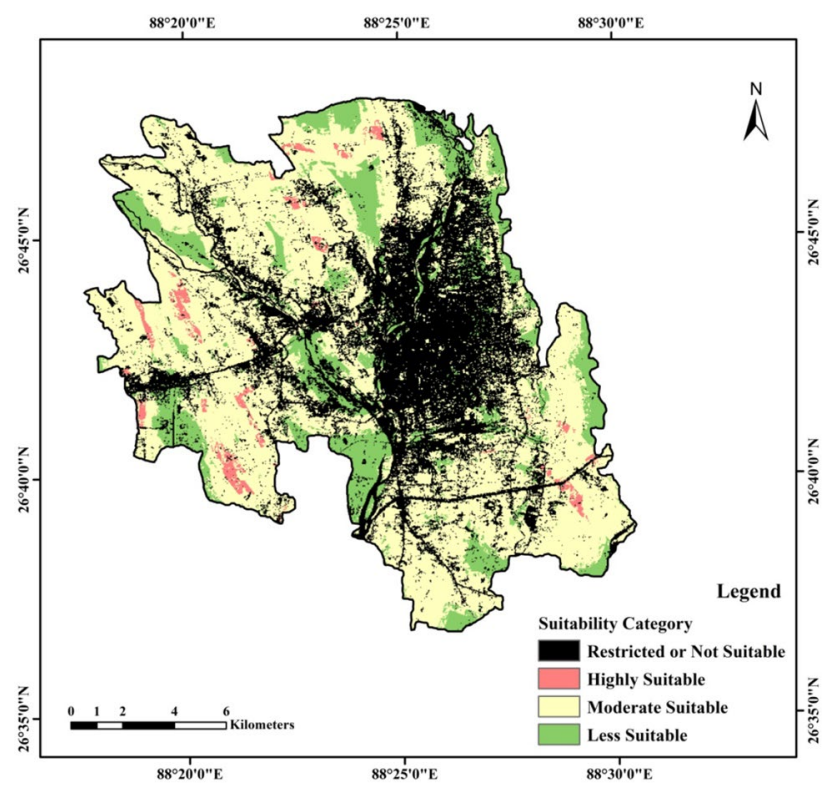

Fig. 7 Final suitability map for built-up development

places for new built-up construction. Parts of Rangapani, Shiabhita, Ranidanga, Bharatsing, Bhujiabani, Mayaram, Baunibhita and Lalman census town have shown their areas as highly suitable area, and there have some reasons behind it. Lalman census town is just beside the national highway and Bagdogra airport, and density of population is also moderate than the others, and maximum available lands are fallow land which makes it highly suitable for new built-up construction. Whereas Uttar Bagdogra, Dakshin Bagdogra, Dumriguri census towns and Kamalpur, Rupsing, Putimari, Batlabari, Tarabari, Paschim karai barir chat have shown moderate suitable places for new built-up construction. Various reasons are there for falling in the category of moderately suitable of these villages and census towns. Uttar Bagdogra, Dumriguri and Dakshin Bagdogra are nearer to the Bagdogra railway station and the national highways, but these are too much congested by its population and different impervious surfaces which makes these places moderately suitable for new built-up construction. But for the villages that are in the moderately suitable category are far apart from the existing facilities, like, railway stations, roads and are nearer to the forest and river, but the density of built-up category and population are moderate, which makes these villages moderately suitable for the new built-up construction. Maximum villages and census towns of Matigara block are in the category of moderately suitable. Reasons behind this are villages and census towns which are nearer to the national highway are already developed by impervious categories and the density of these areas are too high, that is more than 4000 persons per sq. $\mathrm{km}$. and the villages which are at the intermediary part or in the edge of this block, lacks to the road facility and railway stations and also covered by tea gardens or other agricultural lands which makes these villages moderate or less suitable for the new built-up construction (Fig. 7).

Land use land cover and proximity to road are two important factors to delineate suitable places for builtup development. Table 10 shows the distribution of area of each suitability zone that falls in different LULC types. About $99 \%$ area of water bodies has fallen in restricted zone as this category of LULC has been considered as builtup free zone and it should not be captured. About $80 \%$ of agricultural land has fallen in the moderate suitable zone and only $3.5 \%$ area of it is in the highly suitable zone. Same thing has happened in case of wasteland categories. In this, about $68 \%$ area is in the moderate suitable zone and only $1.3 \%$ area is in the highly suitable zone. From Table 11 , it can be said that in the first zone, that is the area which is in the less than $250 \mathrm{~m}$ from road, about 55 and $3.4 \%$ area of it falls in the moderately suitable and highly suitable category, respectively. These two areas can be given priority to set up new construction either for residential or for commercial purposes. About $41 \%$ area of this zone is in the restricted category as this area is already developed by built-up land. A substantial area of next two zones of roads that are 250 to $500 \mathrm{~m}$ and 500 to $750 \mathrm{~m}$ falls in the moderately suitable category. This area can be used mainly for residential uses, as the land price would be cheaper than the first zone. From the fourth zone, the amount of suitable area decreases because of increasing distance.

\section{Conclusion}

In this present growing world, haphazard and unscientific rapid growth of built up is common for maximum cities in the developing nations. So, suitability analysis or suitable site selection for proper urban development has become necessary to overcome the problem of haphazard growth within limited area. To solve this, GIS-based multi-criteria analysis with analytic hierarchy process is simple and 
Table 10 Classes of land use land cover under each suitability categories

\begin{tabular}{|c|c|c|c|c|c|c|c|c|c|c|c|c|}
\hline \multirow{3}{*}{$\begin{array}{l}\text { Suitability } \\
\text { category }\end{array}$} & \multicolumn{10}{|c|}{ Classes of land use land cover } & \multirow{2}{*}{\multicolumn{2}{|c|}{ Total }} \\
\hline & \multicolumn{2}{|c|}{ Water bodies } & \multicolumn{2}{|c|}{ Vegetation } & \multicolumn{2}{|c|}{ Built-up land } & \multicolumn{2}{|c|}{ Agricultural land } & \multicolumn{2}{|c|}{ Wasteland } & & \\
\hline & In $\mathrm{km}^{2}$ & $\ln \%$ & $\ln \mathrm{km}^{2}$ & $\ln \%$ & In $\mathrm{km}^{2}$ & $\ln \%$ & In $\mathrm{km}^{2}$ & $\ln \%$ & In $\mathrm{km}^{2}$ & $\ln \%$ & $\mathrm{ln} \mathrm{km}^{2}$ & $\ln \%$ \\
\hline Restricted & 2.26 & 99.2 & 0.91 & 2.3 & 75.81 & 95.6 & 1.33 & 1.1 & 0.27 & 1.2 & 80.58 & 30.9 \\
\hline Highly & 0.00 & 0.0 & 0.13 & 0.3 & 0.02 & 0.0 & 4.08 & 3.5 & 0.30 & 1.3 & 4.53 & 1.7 \\
\hline Moderate & 0.01 & 0.4 & 25.02 & 63.9 & 2.85 & 3.6 & 93.84 & 79.8 & 15.30 & 68.2 & 137.02 & 52.6 \\
\hline Less & 0.01 & 0.4 & 13.10 & 33.5 & 0.64 & 0.8 & 18.29 & 15.6 & 6.56 & 29.2 & 38.59 & 14.8 \\
\hline Total & 2.28 & 100.0 & 39.15 & 100.0 & 79.32 & 100.0 & 117.54 & 100.0 & 22.43 & 100.0 & 261 & 100 \\
\hline
\end{tabular}

Table 11 Classes of distance from road under each suitability categories

\begin{tabular}{|c|c|c|c|c|c|c|c|c|c|c|c|c|}
\hline \multirow[t]{3}{*}{ Suitability category } & \multicolumn{10}{|c|}{ Classes of distance from road } & \multirow{2}{*}{\multicolumn{2}{|c|}{ Total }} \\
\hline & \multicolumn{2}{|c|}{$<250 m$} & \multicolumn{2}{|c|}{$250 m-500 m$} & \multicolumn{2}{|c|}{$500 m-750 m$} & \multicolumn{2}{|c|}{$750 m-1000 m$} & \multicolumn{2}{|c|}{$>1000 \mathrm{~m}$} & & \\
\hline & $\mathrm{In} \mathrm{km}^{2}$ & $\ln \%$ & $\operatorname{ln~} \mathrm{km}^{2}$ & $\ln \%$ & $\overline{\mathrm{ln} \mathrm{km}^{2}}$ & $\ln \%$ & $\mathrm{In} \mathrm{km}^{2}$ & $\ln \%$ & $\ln \mathrm{km}^{2}$ & $\ln \%$ & $\mathrm{In} \mathrm{km}^{2}$ & $\ln \%$ \\
\hline Restricted & 51.83 & 40.7 & 19.50 & 27.0 & 6.09 & 17.8 & 2.08 & 12.9 & 1.05 & 9.7 & 80.55 & 30.9 \\
\hline Highly & 4.37 & 3.4 & 0.16 & 0.2 & 0.00 & 0.0 & 0.00 & 0.0 & 0.00 & 0.0 & 4.53 & 1.7 \\
\hline Moderate & 69.79 & 54.8 & 46.29 & 64.0 & 18.13 & 53.1 & 2.73 & 16.9 & 0.08 & 0.7 & 137.01 & 52.6 \\
\hline Less & 1.28 & 1.0 & 6.36 & 8.8 & 9.95 & 29.1 & 11.35 & 70.2 & 9.65 & 89.5 & 38.60 & 14.8 \\
\hline Total & 127.27 & 100.0 & 72.31 & 100.0 & 34.17 & 100.0 & 16.16 & 100.0 & 10.78 & 100.0 & 261 & 100 \\
\hline
\end{tabular}

cost efficient technique which can identify various suitability categories within a selected region. Siliguri and its surrounding region also face the same situation due to unprecedented growth of population, and for this, this area has been chosen to find out best places for future built-up development with the consultation of experts and also calculates the amount of different types of suitability lands which will be transferred from different land use and land cover categories in near future which is a newness of this work. This study reveals that only $1.76 \%$ area has been identified as highly suitable area which has located sparsely with a great distant from the core city, whereas maximum area has been categorized as moderately suitable land which is $52.33 \%$ for new construction. The maximum portion of highly suitable area will be come from agricultural land that is $4.08 \mathrm{~km}^{2}$ and the area which is beside the existing road that is $4.37 \mathrm{~km}^{2}$ which reveals that most of the peoples tend to reside just beside the road for easily accessible. Moderately suitable category will also come from agricultural land (79.8\%) followed by wasteland that is $68.2 \%$ and for the road criteria, maximum moderate suitable part will come from 250 to $500 \mathrm{~m}$ category (64\%) followed by $<250 \mathrm{~m}$ category that is $54.8 \%$. This area will be mostly useful for residential purposes as the price of this category will be less than the highly suitable category. Though AHP method has been used in different literatures for the calculation of weightage of different criteria, but it has some limitations which have been experienced while doing this work. It is almost impossible to do with AHP when the number of criteria is above nine because for the pairwise comparison it requires $n(n-1) / 2$ number of comparison. So, we have to limit our criteria at nine, though it can be solved by dividing the criteria into sub-criteria, but after dividing it complicates the model. Another problem is that, we cannot involve more decision makers or experts for the fulfilling of pairwise comparison matrix, as more experts can make the matrix more complicated in assigning weightage values. So we have bound to take only five experts of different fields in this work. Beside these, this type of regional planning work would be helpful for the planners, policy makers, stakeholders, etc., which allows them to identify areas where intensive developmental projects can be implemented in a lucid and efficient way.

Acknowledgement The authors are thankful to the Editor-in-chief and three anonymous reviewers for their constructive suggestions on the manuscript. First author is also thankful to his friend Mr. Kunal Chakraborty for his constant support and encouragement for working on this topic

Author contributions AS contributed to conceptualization, methodology, draft writing, software. RR contributed to conceptualization, supervision, formal analysis, editing. 
Funding This work has been carried out with a financial support from University Grants Commission (UGC), New Delhi, India in the form of Junior Research Fellowship (JRF) award.

Data availability All the data and materials that have been used in this article are openly available in different repository.

\section{Compliance with ethical standards}

Conflict of interest We do not have any conflict of interest regarding the research, authorship and publication of this article.

Open Access This article is licensed under a Creative Commons Attribution 4.0 International License, which permits use, sharing, adaptation, distribution and reproduction in any medium or format, as long as you give appropriate credit to the original author(s) and the source, provide a link to the Creative Commons licence, and indicate if changes were made. The images or other third party material in this article are included in the article's Creative Commons licence, unless indicated otherwise in a credit line to the material. If material is not included in the article's Creative Commons licence and your intended use is not permitted by statutory regulation or exceeds the permitted use, you will need to obtain permission directly from the copyright holder. To view a copy of this licence, visit http://creativecommons .org/licenses/by/4.0/.

\section{References}

1. Bhatta B, Saraswati S, Bandyopadhyay D (2010) Urban sprawl measurement from remote sensing data. ApplGeogr 30:731-740

2. Clark D (1982) Urban geography: An introductory guide. Taylor and Francis

3. Viana CM, Oliveira S, Oliveira SC, Rocha J (2019) Land use/land cover change detection and urban sprawl analysis. Sp Model GIS R Earth Environ Sci. https://doi.org/10.1016/B978-0-12-81522 6-3.00029-6

4. Aburas MM, Abdullah SH, Ramli MF, Ashaari ZH (2015) A review of land suitability analysis for urban growth by using the GISbased analytic hierarchy process. Asian J ApplSci 3(6):869-876

5. Bhatta B (2009) Analysis of urban growth pattern using remote sensing and GIS: a case study of Kolkata India. Int J Remote Sens 30(18):4733-4746

6. Kumar JAV, Pathan SK, Bhanderi RJ (2007) Spatio-temporal analysis for monitoring urban growth- a case study of Indore city. J Indian Soc Remote Sens 35(1):11-20

7. Maktav D, Erbek FS (2005) Analysis of urban growth using multitemporal satellite data in Istanbul Turkey. Int J Remote Sens 26(4):797-810

8. Haas J, Ban Y (2014) Urban growth and environmental impacts in Jing-Jin-Ji, the Yangtze River Delta and the Pearl River Delta. Int J Appl Earth ObsGeoinf 30:42-55

9. Sudhira HS, Ramachandra TV, Jagadish KS (2004) Urban sprawl: metrics dynamics and modelling using GIS. Int J Appl Earth ObsGeoinf 5:29-39

10. Chougale S, Krishnaiah C, Deshbhandari PG (2018) Site suitability analysis for urban development using GIS based multicriteria evaluation technique a case study in ChikoditalukBelagavi district Karnataka India. IOP ConfSer Earth Environ Sci. https://doi. org/10.1088/1755-1315/169/1/012017

11. Parry JA, Ganaie SA, Bhat MS (2018) GIS based land suitability analysis using AHP model for urban services planning in
Srinagar and Jammu urban centers of JK India. J Urban Manag. https://doi.org/10.1016/j.jum.2018.05.002

12. Javadian M, Shamskooshki H, Momeni M (2011) Application of sustainable urban development in environmental suitability analysis of educational land use by using AHP and GIS in Tehran. ProcediaEng 21:72-80

13. Kumar M, Shaikh VR (2013) Site suitability analysis for urban development using GIS based multicriteria evaluation technique: a case study of Mussoorie municipal area Dehradun district Uttarakhand India. IndSoc of Remote Sens 41(2):417-424

14. Bruno G, Genovese A (2018) Multi-criteria decision-making: advances in theory and applications- an introduction to the special issue. Soft Comput 22:7313-7314

15. Turk E, Celik HM (2013) Impacts of planners' different viewpoints on optimum land-use allocation. Eur Plan Stud 21:1937-1957

16. Kumar A, Sah B, Singh AR, Deng Y, He X, Kumar P, Bansal RC (2017) A review of multi criteria decision making (MCDM) towards sustainable renewable energy development. Renew Sustain Energy Rev 69:596-609

17. Zavadskas EK, Antucheviciene J, Chatterjee P (2019) MultipleCriteria Decision-Making (MCDM) Techniques for Business Processes Information Management. Information. http://https:// doi.org/10.3390/info10010004

18. Ullah KM, Mansourian A (2015) Evaluation of land suitability for urban land-use planning: case study Dhaka city. Trans in GIS. https://doi.org/10.1111/tgis.12137

19. Jaybhaye R, Mundhe N, Dorik B (2014) Site suitability for urban solid waste disposal using geoinformatics: a case study of Pune municipal corporation, Maharastra India. Int J Adv Remote Sens GIS 3(1):769-783

20. Paul S (2012) Location allocation for urban waste disposal site using multi-criteria analysis: a study on Nabadwip municipality West Bengal India. Int J GeomatGeosci 3(1):74-88

21. Abdullahi S, Mahmud AR, Pradhan B (2014) Spatial modelling of site suitability assessment for hospitals using geographical information system-based multi-criteria approach at Qazvin city Iran. Geocartolnt 29:164-184

22. Roszkowaska E (2013) Rank ordering criteria weighting methods- a comparative overview. OptimStudiaEkonomiczne 5(65):15-33

23. Pamucar D, Stevic Z, Sremac S (2018) A New Model for Determining Weight Coefficients of Criteria in MCDM Models: Full Consistency Method (FUCOM). Symmetry. http://https://doi. org/10.3390/sym 10090393

24. Chauhan A, Singh A, Jharkharia S (2016) An interpretive structural modelling (ISM) and decision-making trail and evaluation laboratory (DEMATEL) method approach for the analysis of barriers of waste recycling in India. J Air Waste ManagAssoc. https ://doi.org/10.1080/10962247.2016.1249441

25. Sekhar C, Patwardhan M, Vyas V (2017) Study of intellectual capital dimensions in IT industry using DEMATEL method. J InfKnowlManag 16(03):1750022

26. Saaty TL, Vargas LG (2012) Models, methods concepts and applications of the analytic hierarchy process. Springer, Germany

27. Zizovic M, Pamucar D (2019) New model for determining criteria weights: Level Based Weight Assessment (LBWA) model. Deci Mak Appl Manag Eng. https://doi.org/10.31181/dmame19021 $02 z$

28. Saaty TL (1980) The analytic hierarchy process: planning, priority setting resource allocation. McGraw-Hill, New York

29. Das S, Bhattacharya A, Mali S (2013) Study on urban land suitability assessment using remote sensing and GIS: a case study of Khairagarh in Chhattisgarh. Int J ComputAppl 74(10):20-26

30. Weldu WG, Deribew IA (2016) Identification of potential sites for housing development using GIS-based multi-criteria evaluation in Dire Dawa city Ethiopia. Int J Sci Basic Appl Res 28(3):34-49 
31. Bagheri M, Sulaiman WNA, Vaghefi N (2013) Application of geographic information technique and analytical hierarchy process model for land-use suitability analysis on coastal area. J Coast Conserv 17(1):1-10

32. Thapa RB, Murayam Y (2010) Drivers of urban growth in the Kathmandu valley, Nepal: examining the efficacy of the analytic hierarchy process. ApplGeogr 30(1):70-83

33. Khoi DD, Murayama Y (2012) Land suitability assessment using a fuzzy multi-criteria evaluation. Prog Geospatial Anal. https:// doi.org/10.1007/978-4-431-54000-7_14

34. Al-Kheder S, Wang J, Shan J (2008) Fuzzy inference guided cellular automata urban-growth modelling using multi-temporal satellite images. Int J GeographInfSci 22(11-12):1271-1293

35. Yang F, Zeng G, Du C, Tang L, Zhou J, Li Z (2008) Spatial analyzing system for urban land-use management based on GIS and multi-criteria assessment modelling. Prog Nat Sci 18:1279-1284

36. Park S, Jeon S, Kim S, Choi C (2011) Prediction and comparison of urban growth by land suitability index mapping using GIS and RS in South Korea. Landsc Urban Plan 99(2):104-114
37. Jain K, Subbaiah YV (2007) Site suitability analysis for urban development using GIS. J ApplSci 7(18):2576-2583

38. Saaty TL (2004) Decision making- the analytic hierarchy and network processing (AHP/ANP). J SystSciSystEng 13(1):1-35

39. Saaty TL (2000) Fundamentals of decision making and priority theory. RWS Publications, Pittsburgh

40. Deng JS, Wang K, Deng YH, Qi GJ (2008) PCA-based land-use change detection and analysis using multitemporal and multisensory satellite data. Int J Remote Sens 29(16):4823-4838

41. Saaty TL (1977) A scaling method for priorities in hierarchical structures. J Math Psychol 15(3):234-281

42. Rawat JS (2010) Database management system for khulgard watershed, Kumaun Lesser Himalaya Uttarakhand India. CurrSci 98(10):1340-1348

43. Mishra AK, Deep S, Choudhary A (2015) Identification of suitable sites for organic farming using AHP \& GIS. Egypt J Remote Sens Space Sci. https://doi.org/10.1016/j.ejrs.2015.06.005

Publisher's Note Springer Nature remains neutral with regard to jurisdictional claims in published maps and institutional affiliations. 